\section{Malus Germplasm Varies in Resistance or Tolerance to Apple Replant Disease in a Mixture of New York Orchard Soils}

\author{
Dorcas K. Isutsa ${ }^{1}$ and Ian A. Merwin ${ }^{2}$ \\ Department of Fruit and Vegetable Science, Cornell University, Ithaca, \\ NY 14853-0327 \\ Additional index words. accession, root-lesion nematode, Pratylenchus penetrans, dagger \\ nematode, Xiphinema americanum, rootstock, orchard replant problem, Pythium, \\ Cylindrocarpon, Fusarium, Rhizoctonia, Phytophthora
}

\begin{abstract}
We tested 40 seedling lots and 17 clonal accessions-representing 941 genotypes and 19 species or interspecific hybrids of Malus - for their resistance or tolerance to apple replant disease (ARD) in a mixture of five New York soils with known replant problems. Total plant biomass, root necrosis, root-infesting fungi, and root-lesion nematode (RLN; Pratylenchus penetrans Cobb) or dagger nematode (DN; Xiphinema americanum Cobb) populations were evaluated in apple seedlings and clones grown for $\approx 60$ days in the composite soil. In addition to phytophagous nematodes, various Pythium, Cylindrocarpon, Fusarium, Rhizoctonia and Phytophthora species were isolated from roots grown in the test soil. Plant growth response was categorized by a relative biomass index (RBI), calculated as total plant dry weight in the pasteurized field soil (PS) minus that in an unpasteurized field soil (FS), divided by PS. Nematode reproduction on each genotype was defined by a relative reproduction index (RRI), calculated as final nematode populations in roots and soil (Pf) minus initial soil populations (Pi), divided by Pi. The RBI, RRI, and other responses of accessions to ARD soil were used to rate their resistance, tolerance, or susceptibility to apple replant disease. None of the accessions was completely resistant to ARD pathogens in our test soil. Seedling accessions of $M$. sieversii Roem. and $M$. kirghisorum Ponom. appeared to have some tolerance to ARD, based upon their low RRIs and RBIs. Three clonal rootstock accessions (G.65, CG.6210, and G.30), and four other clones (M. baccata Borkh.-1883.h, M. xanthocarpa Langenf.-Xan, M. spectabilis Borkh.PI589404, and $M$. mandshurica Schneid.-364.s) were categorized as tolerant to ARD. The disease response of other accessions was rated as susceptible or too variable to classify. We concluded that sources of genetic tolerance to ARD exist in Malus germplasm collections and could be used in breeding and selecting clonal rootstocks for improved control of orchard replant pathogens.
\end{abstract}

Apple replant disease (ARD) is a soilborne disease syndrome that often stunts tree growth and reduces yields when orchards are renovated (Mai and Abawi, 1981; Mazzola, 1998). The etiology of replant problems varies across major fruit-growing regions, and biotic or abiotic factors acting individually or synergistically are involved in many New York orchards (Mai et al, 1994; Merwin and Stiles, 1989; Traquair, 1984). Previously implicated biotic factors include pathogenic actinomycetes (Otto et al., 1993), bacteria (Utkhede et al., 1992), fungi (Mazzola, 1998; Sewell, 1981), and nematodes such as RLN (Mai et al., 1994) or DN (Sultan and Ferris, 1991). Abiotic fac-

Received for publication 18 Apr. 1999. Accepted for publication 17 Aug. 1999. Use of trade names does not imply endorsement of the products named or criticism of similar ones not named. The cost of publishing this paper was defrayed in part by the payment of page charges. Under postal regulations, this paper therefore must be hereby marked advertisement solely to indicate this fact.

${ }^{1}$ Formerly a graduate student at Cornell Univ.; now Senior Lecturer at Egerton University, P.O. Box 536, Njoro, Kenya.

${ }^{2}$ Associate Professor; to whom reprint requests should be addressed (e-mail: im13@cornell.edu). objective in this research was to evaluate diverse apple genotypes for potential sources of effective resistance or tolerance to the replant disease syndrome.

\section{Materials and Methods}

Sources and identification of germplasm. Several thousand accessions of wild-type and domesticated apples, representing more than 30 species of Malus collected throughout the northern hemisphere, have been acquired by the U.S. Dept. of Agriculture (USDA) Agricultural Research Service (ARS) Plant Germplasm Repository Unit (PGRU) in Geneva, N.Y. (Forsline, 1988). To evaluate the ARD susceptibility of this germplasm, we selected accessions from temperate climate regions with soilborne pathogens comparable to those in the northeastern United States. We also tested some experimental transgenic clones, and seven advanced rootstock selections-interspecific hybrids referred to as the Cornell-Geneva (CG., or G. series) rootstocks-developed and selected for disease resistance and desirable horticultural characteristics (Cummins and Aldwinckle, 1983).

Recognizing the variable and site-specific etiology of ARD (Mai and Abawi, 1981; Mazzola, 1998; Sewell,1981), we used a mixture of soils from orchards with known replant problems to test the growth responses of selected apple genotypes to an ARD complex representative of New York orchards. To determine which pathogens may have been involved in the observed disease symptoms and growth responses, we also isolated and identified putative fungal and nematode pathogens from apple roots grown in our ARD soils mixture.

Open-pollinated seedling lots were obtained from 40 Malus accessions, and microshoot cultures from 17 Malus clones at the Geneva ARS-PGRU, in quantities ranging from one to five microshoot cultures and 25 to 600 seeds per accession. Because of variation in germination or propagation of various accessions and greenhouse space limitations, we tested accessions continuously from June 1995 to Oct. 1997. This temporal blocking factor was estimated and adjusted for in statistical analyses of data.

In a related experiment to isolate and identify potential pathogenic fungi from our ARD soil, and to investigate the influence of Agrobacterium-inserted transgenic endochitinase on apple responses to ARD, we obtained five additional clones as sterile tissueculture microshoots from the research program of Drs. H. Aldwinckle and J. Norelli at the New York State Experimental Station in Geneva, N.Y.: M. spectabilis-PI589404 (also tested in the main experiment), M.7a rootstock and 'Marshall McIntosh' (as standard controls), G.5A rootstock, gus-marker transgenic Marshall McIntosh-T28 (as a transformation vector control), endochitinase transgenic Marshall McIntosh-T565, and endochitinase transgenic Royal Gala-T348 (Bolar et al., 1997).

For identification and comparisons of the 
accessions tested, in this report we have followed PGRU protocols that assign each accession a germplasm reference inventory number (GRIN) consisting of its binomial plus a plant introduction (PI) or Geneva Malus (GMAL) number and suffix. Open-pollinated seedling lots are referred to as "seedlings" and vegetatively propagated clonal lines as "clones." For example, seedling M. fusca Rehd.-PI 600204 represents an open pollinated seedling lot obtained from a unique accession; CG.6210 (formerly CG.210) is an interspecific hybrid rootstock obtained as clonal microshoots; and $M$. mandshurica-GMAL 364.s is a clonal accession obtained from tissue-culture as vegetative microshoots. Information on these accessions is available on the worldwide web at www.ars-grin.gov/cgi-bin/npgs/html/search.pl.

Germplasm propagation. Seeds were surface-disinfected in $20 \% \mathrm{NaOCl}$, dusted with $50 \%$ WP captan $(3 \alpha, 4,7,7 \alpha$-tetrahydro-2[(trichloromethyl)thio]- $1 H$-isoindole-1,3(2H)dione) fungicide, and stratified at $5{ }^{\circ} \mathrm{C}$ in layers of moist blotting paper, polyacrylamide gel, or vermiculite. After germination (varying from 1 to 4 months) sprouted seedlings were transferred to sterile vermiculite or 1 peat : 1 perlite mix (by volume) for 14 to $21 \mathrm{~d}$ of growth prior to selection for transplanting into ARD bioassay soil. Clonal microshoot cultures were proliferated in synthetic media under sterile conditions and rooted under mist as described by Isutsa et al. (1998).

Sources and characteristics of ARD soils. Based on previous ARD diagnostic bioassays of soil from 25 regional orchards with replant problems (Merwin, 1995; Pruyne et al., 1994) we selected five orchards with representative soils for New York. These sites had been in fruit production for 50 to 100 years, and at sampling time they included mature bearing, recently fallowed, and newly replanted orchards. Several soils had elevated residues of lead arsenate from pesticide applications in the early 1900s, but previous research had indicated that heavy metal residues did not stunt apple seedling growth in these soils (Merwin et al., 1994).

To provide sufficient soil for repeated test runs and minimize the negative effects of long-term cold storage on soilborne inoculum, we collected $\approx 500 \mathrm{~kg}$ of fresh soil from each orchard on four occasions (18 May 1995, 13 Oct.1995, 5 July 1996, and late Sept. to early Oct.1996). In taking samples, vegetation was scraped off the soil surface of inter-row spaces (alleyways) in a random pattern, then topsoil was obtained with a hand shovel down to 20 $\mathrm{cm}$ depth at 40 to 50 locations in each orchard. Samples were bulked in black polyethylene bags and stored at $4{ }^{\circ} \mathrm{C}$ prior to mixing for subsequent use. Subsamples were taken for analysis of nutrient availability and $\mathrm{pH}$; nematodes were extracted by modified Baermann pie-pan elutriation and identified as to genus and species (Mai and Mullin, 1996). The individual soils were then homogenized (composited) in a small concrete mixer and another subsample was taken for analysis of essential plant nutrient availability, $\mathrm{pH}$, physical texture, and parasitic nematode counts. The bulked soil mixture was then halved; the half to be used as unpasteurized field soil (FS) was returned to cold storage at $4{ }^{\circ} \mathrm{C}$, and the other half (PS) was pasteurized with aerated steam at $75^{\circ} \mathrm{C}$ for 30 to $40 \mathrm{~min}$, and then air-dried in a greenhouse. After $10 \mathrm{~d}$, the PS mix was bagged and returned to the same cold storage room as the FS mixture.

Soil texture and nutrient availability. Our soil mixture had a sandy loam texture with proportions of sand, silt, and clay of $50 \%$, $40 \%$, and $8 \%$, respectively. Comparisons of extractable plant nutrients and $\mathrm{pH}$ in FS and PS indicated there were negligible effects of pasteurization on nutritional status-although $\mathrm{Mn}$ and $\mathrm{NO}_{3}$ availability were slightly greater in FS than in PS. Soil organic matter content (w/w basis) was $4.0 \%$ and $3.8 \%$ in FS and PS, respectively, and the $\mathrm{pH}$ (6.3 for FS and 6.4 for PS) and essential plant nutrient availability in both soil treatments were within optimal ranges for apple (Stiles and Reid, 1991). The abiotic (physical and chemical) effects of soil pasteurization were thus unlikely to have caused substantial plant growth differences in FS relative to PS (Merwin and Stiles, 1989).

Evaluating plant growth in FS and PS bioassays. The number of plants (observations) available for evaluation in FS and PS varied among accessions, because of the different germination rates and requirements of seed lots, and erratic proliferation, acclimation, and rooting of different clones subjected to the environmental conditions in our greenhouse. Ten to 100 seedlings or clonal plantlets were available for each accession, and the number of plants deemed sufficiently uniform (based on size and number of leaves, and size of root systems) for transplanting into ARD soil ranged from six to 30 per accession. Twenty plants (10 each in FS and PS) was the usual number bioassayed per given accession in a single test period, and accessions that were readily propagated were evaluated two times in successive samples of the ARD soil, with observations pooled for statistical analyses. A total of 1344 plants ( 924 for seedlings and 420 for clones) were evaluated.

Plants with four to six leaves were transferred into ARD soil after several weeks of postgermination growth at 23 to $27^{\circ} \mathrm{C}$ with 16 $\mathrm{h}$ of supplemental and daylight in a greenhouse. Before transplanting, the germination medium was gently rinsed from roots, and initial fresh weights were recorded as a covariate for statistical analyses. Sterilized clay pots were filled with $0.8 \mathrm{~L}$ of PS or FS, a single test plant was transplanted into each pot, and the pots were randomly arranged in a greenhouse with temperature and light as described previously.

Plants were watered every other day during the first 4 weeks, daily during the next 4 weeks, and twice daily as needed to keep the soil moist approaching harvest time. Each plant was fertilized weekly with a $50-\mathrm{mL}$ aliquot of tap water containing $3 \mathrm{~g} \cdot \mathrm{L}^{-1}$ of a complete fertilizer $(15 \mathrm{~N}-5 \mathrm{P}-17 \mathrm{~K})$ providing essential macro- and micro-nutrients (Peters Excel; Scotts-Sierra Co., Marysville, Ohio). When necessary, powdery mildew (Podo- sphaera leucotricha Ellis \& Everh.) was controlled with fenarimol fungicide $(\alpha-(2-$ chlorophenyl)- $\alpha$-(4-chlorophenyl)-5pyrimidinemethanol), and arthropod pests were controlled with foliar applications of pyrethroid insecticides. Weed seedlings that germinated in FS pots were uprooted soon after emergence.

Harvesting and processing plants. The plants were harvested $\approx 60 \mathrm{~d}$ after transplanting. Shoots and leaves were separated from roots and placed in paper bags for drying to constant weight at $72{ }^{\circ} \mathrm{C}$; soil was gently shaken and massaged from each root system, then mixed before subsampling $100 \mathrm{~cm}^{3}$ of soil for nematode counts. The soil samples were stored at $4{ }^{\circ} \mathrm{C}$ until parasitic nematodes could be extracted (within a week) and identified as previously described.

Roots were washed gently in running tap water, blotted dry, and necrosis was rated visually on a five-class scale of 0 to 4 , indicating $0 \%, 1 \%$ to $25 \%, 26 \%$ to $50 \%, 51 \%$ to $75 \%$ and $76 \%$ to $100 \%$ dead or necrotic root system, respectively. One-gram samples of nonsuberized, intact feeder-roots were taken randomly from each root system for counting RLNs, using a modified acid fuchsin tissuestaining procedure (Byrd et al., 1983). The remainder of the root system of each plant was then dried at $72{ }^{\circ} \mathrm{C}$ and weighed separately.

Isolating and identifying fungi from roots. Based upon previous reports of fungi associated with ARD, we chose isolation methods to detect Pythium, Fusarium, Rhizoctonia, Phytophthora, and Cylindrocarpon species within the roots of six clones (five different from and one identical with those in our main experiment) grown in FS (Braun, 1995; Jaffee et al., 1982; Mazzola, 1998). We did not attempt to isolate fungal root pathogens from seedlings, because they were not sterile when obtained and could have been infested with fungi prior to germination.

For fungal identifications, 10 sterile microshoots of the six clones were rooted under mist in sterile vermiculite, grown in the FS mixture and harvested after $60 \mathrm{~d}$ as previously described. Roots were washed in running tap water for $2 \mathrm{~min}$, cut into 1-cm-long pieces, surface-disinfected in $10 \% \mathrm{NaOCl}$ for $2 \mathrm{~min}$, then rinsed twice in sterilized, distilled water. Root pieces were blotted dry on sterile paper, randomly selected, and cultured onto selective isolation and identification media. Fusarium, Rhizoctonia, and Cylindrocarpon were isolated by culturing six to nine root pieces of each host plant on half-strength potato dextrose agar (PDA) amended with ampicillin and rifampicin. Small pieces of agar containing unique colonies were subcultured separately within $3 \mathrm{~d}$ to PDA or cornmeal agar for identification as to genus and recording of frequency (Jaffee et al., 1982).

Thereafter, single spores or hyphal tips of Fusarium and Cylindrocarpon were subcultured on carnation (Dianthus caryophyllus L.) leaf agar or PDA for Fusarium, and PDA for Cylindrocarpon (Samuels and Brayford, 1990). Fusarium species were identified following the procedures outlined by Nelson et al. (1983) 
based on the presence or absence and size of phialides, microconidia, macroconidia, and mycelial chlamydospores, and the color of sporodochia. Cylindrocarpon species were identified based on the size of microconidia, macroconidia, and mycelial chlamydospores (Booth, 1966). Pythium species were isolated and identified only as to the genus, by culturing three root pieces from each host plant on water agar amended with rifampicin and pimaricin (Sewell, 1981).

For isolation and identification of Phytophthora species, roots with symptoms were washed in tap water for 3 min, surfacedisinfected in $70 \%$ ethanol for $2 \mathrm{~s}$, rinsed three times in distilled water, blotted dry on sterilized paper, and cut into $1-\mathrm{cm}-\mathrm{long}$ pieces. Nine root sections from each host plant were randomly selected and cultured on selective media containing cornmeal agar, pimaricin, ampicillin, rifampicin, $\mathrm{PCNB}$, and hymexazol (P5ARPH). After $3 \mathrm{~d}$ at $21{ }^{\circ} \mathrm{C}$, emerging colonies were subcultured on cornmeal and V8 juice (Campbell Soup Co., Camden, N.J.) agar for species identification based on morphology of colony, sporangia, and oogonia (Wilcox, 1989).

Presenting and analyzing data. Data were square-root transformed to stabilize variance and attain normality before analysis using SAS (SAS Institute, Cary, N.C.) or SPSS (SPSS, Chicago) programs as appropriate. The data for seedling and clonal accessions were analyzed separately, with sources of variation as soil treatment (PS or FS), accession (subplot), bioassay date (block), and initial transplant size (covariate). Because the number of observations per treatment combination (three to 30 per accession) and number of blocks over time (one to three per accession) differed, our experimental design had rank deficiency, so the SAS "Mixed Procedure," which fits linear models with both fixed and random factors, was used for analysis. We used a relative biomass index (RBI) to normalize experimental variance within and among accessions, and to quantify and compare plant growth responses to ARD. Each RBI was calculated as the total plant dry weight (TDPW) in FS subtracted from TDPW in PS, divided by TDPW in PS, i.e. (PS - FS)/PS. An accession RBI value not significantly $>0$ (based on $t$ tests at $P \leq 0.05$ ) therefore indicated relatively good growth of that accession in FS vs. PS, and its potential tolerance or resistance to the ARD complex in our soils mixture.

In categorizing general host-plant responses to $\mathrm{ARD}$, and more specifically the relative reproductive success of parasitic nematodes on each accession, we followed the terminology of Young (1998): a "susceptible" host response denotes one where the pathogen(s) reproduce successfully and disease symptoms are evident and extensive in the host plant; a "tolerant" response implies successful reproduction of pathogen(s) but moderate or nondebilitating symptoms in the host plant; and a "resistant" response implies poor reproduction by pathogen(s) and few or no visible disease symptoms in the host plant.

The increase or decrease of RLN and DN populations in roots and soil for each accession was quantified by a relative reproduction index (RRI), calculated as the final root and soil nematode populations per gram root fresh weight plus $100 \mathrm{~cm}^{3}$ soil at harvest $(\mathrm{Pf})$, minus the initial populations $(\mathrm{Pi})$ in nonpasteurized FS, divided by $\mathrm{Pi}$, i.e., (Pf - Pi)/Pi. An accession RRI value not significantly $>0$ (based on $t$ tests at $P \leq 0.05$ ) indicated relatively poor reproduction of, and potential host-plant resistance to, the parasitic nematodes in our soil mix. The isolation frequency for fungal pathogens in roots was analyzed by a chi square test to determine significant differences among fungi or host-plant accessions.

\section{Results and Discussion}

ARD soil nematode populations. The RLN and DN populations in our composite ARD soil varied somewhat in successive collections from the same orchards. After mixing the soils from all orchards, mean populations were $60 \mathrm{RLN}$ and $50 \mathrm{DN}$ per $100 \mathrm{~cm}^{3}$ of soil containing small root fragments in the ARD mixture collected June 1995, and 420 RLN and $50 \mathrm{DN}, 438 \mathrm{RLN}$ and $70 \mathrm{DN}$, and $90 \mathrm{RLN}$ and $10 \mathrm{DN}$ in the soils collected Oct. 1995, July 1996, and Sept.-Oct. 1996, respectively. These changes in nematode populations over time are consistent with previous reports for temperate zone soils, and we used RRIs to compensate for differences in Pi from one test run to another(McSorley, 1998; Melakeberhan et al., 1993). The textural properties of our ARD soil were relatively favorable for RLN and DN dispersal, reproduction, and infestation of fruit-tree roots (Mai and Abawi, 1981). The RLN and DN populations from our initial soil samples and the composite mixture were comparable with populations in other soils with severe apple replant problems (Jaffee et al., 1982; Mai et al., 1994; Pruyne et al., 1994), and substantially higher than previously estimated injury thresholds of 20 to 50 RLN per $100 \mathrm{~cm}^{3}$ of soil (Hoestra and Oostenbrink, 1962).

Fungi isolated from apple roots grown in $A R D$ soil. We isolated various species of Fusarium, Cylindrocarpon, Pythium, Rhizoctonia, Mortierella, Trichoderma, Penicillium, Chaetomium, Rhizopus, and Mucor from the root systems of six clonal accessions after growth in our composite test soil. However, the present report includes only observations of Fusarium, Pythium, Cylindrocarpon, Rhizoctonia, and Phytophthora species previously associated with replant disease symptoms, and isolated from roots in our nonpasteurized (FS) test soil (Braun, 1995; Jaffee et al., 1982; Mai et al., 1994; Mazzola, 1998).

The mean frequency of isolation from all root systems $(\mathrm{n}=18)$ varied among fungal genera and host accessions (chi square tests at $P \leq 0.05$ ). Pythium species were isolated from $29 \%$ of all root samples, Fusarium from $26 \%$, Phytophthora from 23\%, Cylindrocarpon from $12 \%$, and Rhizoctonia from 1\%. Among the four Fusarium species identified, F. oxysporum Schlectend. was the most prevalent $(22 \%)$. Of the five Phytophthora species identified, $P$. cryptogea Pethybyr. \& Lafferty occurred in $10 \%$ of all root samples, $P$. cactorum Lebert \& Cohn and $P$. cambivora (Petri) Buisman in 4\%, P. megasperma Drechs. in 3\%, and another unknown Phytophthora sp. in $2 \%$ of roots sampled. The frequency of $C$. lucidum Wollenweb. was $7 \%$, and of $C$. destructans Zinssmeister 5\%. The proportions of clonal accessions infested by each fungus were $100 \%$ for Pythium (not identified to species level) and $F$. oxysporum, $83 \%$ for Phytophthora sp., $50 \%$ for $C$. lucidum and C. destructans, and $17 \%$ for F. solani (Mart.) Sacc., F. equiseti (Corda.) Sacc., F. acuminatum Ellis \& Everh., and one Rhizoctonia species.

Although one of the endochitinase transgenic clones (Marshall McIntosh-T565) was the only accession from which no species of Phytophthora was isolated, there were no consistent differences among the six clones evaluated in RLN reproduction, root disease symptoms, or apparent susceptibility to the soilborne fungi in our test soil. Following up on these observations, the endochitinase activity was assayed and found to be relatively low in the transgenic clones we had evaluated, for unknown reasons (Isutsa, 1998).

These observations suggest that ARD symptoms in our main experiment were associated with a complex of soilborne pathogens, including RLN and at least five fungal genera known to include species pathogenic to apple (Mai et al., 1994; Mazzola, 1998). The accessions that performed well in our ARD soil were therefore probably resistant to, or tolerant of, several of the root pathogens implicated in New York apple replant problems.

Comparing plant growth in FS and PS. The roots and shoots of seedlings and clonal accessions grown in PS appeared to be consistently healthy. In contrast, plants grown in FS usually exhibited typical ARD symptoms, such as stunted and necrotic secondary feeder roots, foliar symptoms of multiple nutrient deficiencies, reduced leaf area, and shortened internode length (Mai and Abawi, 1981). Root necrosis indices ranged from two to four $(21 \%$ to $80 \%$ of roots affected) but did not differ among accessions grown in FS (data not shown); root lesions and necrosis were not observed on any accessions grown in PS.

Individual plants and accession cohorts that were relatively robust when transplanted into the ARD bioassay soil tended to perform better subsequently than did smaller transplants, and initial plant fresh weight was a significant covariate factor in the final seedling and clonal biomass at harvest. Others have also reported that larger transplants were more tolerant of some soilborne pathogens (Fernandez et al., 1995; Jaffee and Mai, 1978).

The final biomass of root and shoot organs varied substantially, both among the accessions and between the FS and PS treatments. However, within soil treatments and grouped observations of each accession, the relative trends in root and shoot biomass were quite consistent, i.e., the above- and below-ground biomasses were similarly small, moderate, or large for each accession/soil treatment combi- 
nation (data not shown). To simplify data analysis and presentation, we therefore combined root and shoot dry weights into total plant biomass values.

The average total dry weights of seedling accessions ranged from 0.13 to $3.04 \mathrm{~g} / \mathrm{plant}$ in FS, and from 0.67 to $8.35 \mathrm{~g} /$ plant in PS (Table 1). Malus sieversii-PI600427 had the largest and M. angustifolia Rehd.-PI589773 the smallest biomass in FS; however, in PS the seedlings of M. angustifolia-PI600091 were the largest, and M. ioensis Rehd.-PI600232 the smallest. In other words, most accessions grew better in PS than in FS, but the range of biomass responses to FS and PS differed substantially among seedling lots.

Biomass of clonal accessions ranged from 0.24 to $4.87 \mathrm{~g} /$ plant in FS, and 0.63 to $7.79 \mathrm{~g} /$ plant in PS (Table 2). The G.65 rootstock grew the largest in both FS and PS treatments, whereas M. micromalus Rehd.-1882.g was the smallest in both FS and PS. However, this consistency was not sustained for most other clones; as with seedlings, the relative growth responses of clonal accessions to FS and PS were often quite different. Therefore, to interpret seedling or clonal accession responses to ARD three factors were considered: 1) the general appearance and relative differences among seedlings and clones in PS, as an indication of possible abiotic or environmental limitations under our greenhouse test conditions; 2) the magnitude and variance of differences between each accession's biomass in FS compared with PS; and 3) the normalized relative biomass indices (RBIs) of each accession compared with a zero or null growth response to ARD soil pasteurization.

Total plant biomass and differences in FS vs. PS. The mean dry-weight values for 36 of the seedling accessions and eight of the clones were significantly greater in PS than in FS ( $P$ $\leq 0.05$ ) (Tables 1 and 2). The growth responses of the remaining four seedling lots and nine clonal accessions were not significantly different in FS compared with PS. A minimal growth response to soil pasteurization may have indicated accession resistance or tolerance to ARD pathogens, but could also have resulted from growth limitation by dwarfing genetic factors or unfavorable abiotic conditions in our testing environment and procedures. To differentiate between these responses, we assumed that the greatest accession-mean biomass values in PS $(8.4 \mathrm{~g}$ for seedlings and $7.8 \mathrm{~g}$ for clones) represented upper limits for their potential growth under favorable abiotic and biotic conditions. We also assumed that average biomass values in PS for the aggregated populations of seedlings $(3.8 \mathrm{~g})$ and clones $(4.0 \mathrm{~g})$ provided a reference point for normal growth under our test conditions (Sewell et al., 1992). Given these assumptions, none of the seedling accessions appeared to be tolerant of ARD, because the four seedling lots with equivalent biomass in FS and PS all grew poorly in both soil treatments (Table 1).

Six of the clonal accessions grew well in both FS and PS, and may have been tolerant of the ARD complex in our soil mix; these were
Table 1. Total and relative biomass of seedling Malus accessions grown $\approx 60 \mathrm{~d}$ in a composite field soil infested with apple replant pathogens (FS) or steam pasteurized (PS). Accessions are ranked by relative biomass indices (RBIs).

\begin{tabular}{|c|c|c|c|c|c|c|}
\hline \multirow[b]{2}{*}{ Seedling accessions } & \multirow{2}{*}{$\begin{array}{c}\text { Plants } \\
\text { (n) }\end{array}$} & \multicolumn{4}{|c|}{ Biomass (g/plant) } & \multirow[b]{2}{*}{$\mathrm{RBI}^{\mathrm{y}}$} \\
\hline & & FS & PS & Pooled SE & $P^{\mathrm{z}}$ & \\
\hline M. angustifolia-PI589773 & 5 & 0.13 & 1.01 & 0.29 & NS & $0.87^{*}$ \\
\hline M. orientalis-GMAL1461.k & 15 & 1.11 & 4.30 & 0.13 & $*$ & $0.77^{*}$ \\
\hline M. sieversii-PI600424 & 5 & 1.03 & 4.20 & 0.21 & $*$ & $0.77^{*}$ \\
\hline M. prunifolia-PI589816 & 15 & 0.97 & 4.05 & 0.12 & $*$ & $0.77^{*}$ \\
\hline M. sieversii-PI600559 & 10 & 0.72 & 3.01 & 0.15 & $*$ & $0.77^{*}$ \\
\hline M. sieversii-PI600460 & 7 & 1.84 & 7.94 & 0.21 & $*$ & $0.76^{*}$ \\
\hline M. orientalis-GMAL1461.c & 15 & 1.12 & 5.47 & 0.12 & $*$ & $0.76^{*}$ \\
\hline M. komarovi-PI600416 & 5 & 1.23 & 4.70 & 0.16 & $*$ & $0.76^{*}$ \\
\hline M. angustifolia-PI589770 & 15 & 0.75 & 3.07 & 0.13 & $*$ & $0.75^{*}$ \\
\hline M. spectabilis-PI588893 & 15 & 1.38 & 4.65 & 0.13 & $*$ & $0.74^{*}$ \\
\hline M. sieboldii-PI600029 & 6 & 0.62 & 3.42 & 0.21 & $*$ & $0.74^{*}$ \\
\hline M. kirghisorum-PI590043 & 15 & 2.08 & 6.95 & 0.13 & $*$ & $0.72^{*}$ \\
\hline M. prunifolia-PI594109 & 16 & 0.97 & 3.93 & 0.13 & $*$ & $0.72^{*}$ \\
\hline M. sieversii-PI600496 & 12 & 1.17 & 3.92 & 0.15 & $*$ & $0.72^{*}$ \\
\hline M. baccata-PI589838 & 16 & 1.37 & 4.12 & 0.12 & $*$ & $0.71^{*}$ \\
\hline M. ioensis-PI600275 & 10 & 0.66 & 2.24 & 0.28 & $*$ & $0.70^{*}$ \\
\hline M. kirghisorum-PI589380 & 15 & 1.76 & 5.26 & 0.13 & $*$ & $0.67^{*}$ \\
\hline M. fusca-PI600204 & 8 & 0.91 & 2.44 & 0.21 & $*$ & $0.67^{*}$ \\
\hline M. sieversii-PI600571 & 10 & 0.73 & 2.43 & 0.16 & $*$ & $0.67^{*}$ \\
\hline M. ioensis-PI590008 & 15 & 0.70 & 2.37 & 0.13 & $*$ & $0.67^{*}$ \\
\hline M. angustifolia-PI600091 & 7 & 2.87 & 8.35 & 0.20 & $*$ & $0.66^{*}$ \\
\hline M. ioensis-PI590015 & 15 & 0.62 & 1.90 & 0.13 & $*$ & $0.65^{*}$ \\
\hline M. kirghisorum-PI600459 & 4 & 2.21 & 5.74 & 0.20 & $*$ & $0.64^{*}$ \\
\hline M. orientalis-PI600009 & 18 & 1.60 & 3.45 & 0.14 & $*$ & $0.61^{*}$ \\
\hline M. coronaria-PI600130 & 3 & 0.39 & 1.00 & 0.21 & NS & $0.60^{*}$ \\
\hline M. ioensis-PI600232 & 3 & 0.29 & 0.67 & 0.25 & NS & $0.60^{*}$ \\
\hline M. sieversii-PI600489 & 12 & 1.03 & 2.87 & 0.14 & $*$ & $0.58^{*}$ \\
\hline M. baccata-PI437055 & 10 & 2.15 & 4.87 & 0.14 & $*$ & $0.57^{*}$ \\
\hline M. baccata-PI286599 & 15 & 2.40 & 5.19 & 0.13 & $*$ & $0.52^{*}$ \\
\hline M. spectabilis-PI594100 & 20 & 1.39 & 2.51 & 0.13 & $*$ & $0.52^{*}$ \\
\hline M. baccata-PI588870 & 15 & 2.11 & 4.29 & 0.12 & $*$ & $0.50^{*}$ \\
\hline M. kirghisorum-PI600475 & 14 & 2.86 & 4.89 & 0.21 & $*$ & $0.49^{*}$ \\
\hline M. kirghisorum-PI600478 & 4 & 3.07 & 5.74 & 0.20 & $*$ & $0.47^{*}$ \\
\hline M. prunifolia-PI589930 & 17 & 1.45 & 3.06 & 0.12 & $*$ & $0.45^{*}$ \\
\hline M. prunifolia-PI594102 & 15 & 1.51 & 2.90 & 0.13 & $*$ & $0.44^{*}$ \\
\hline M. ioensis-PI589999 & 15 & 1.36 & 2.55 & 0.12 & $*$ & $0.44^{*}$ \\
\hline M. angustifolia-PI589727 & 15 & 1.51 & 4.59 & 0.33 & $*$ & $0.41^{\mathrm{NS}}$ \\
\hline M. sieversii-PI600427 & 8 & 3.04 & 4.46 & 0.21 & $*$ & $0.33^{*}$ \\
\hline M. sieversii-PI600563 & 14 & 2.21 & 3.34 & 0.14 & $*$ & $0.21^{*}$ \\
\hline M. sieversii-PI600539 & 8 & 0.72 & 1.41 & 0.15 & NS & $0.19^{\mathrm{Ns}}$ \\
\hline
\end{tabular}

${ }^{\mathrm{z}}$ Significant $(*)$ or nonsignificant (NS) difference between mean dry weights in FS and PS for each accession based on Tukey-Kramer tests at $P \leq 0.05$.

${ }^{\mathrm{y}}$ Calculated as (PS - FS)/PS, rated $\leq 0(\mathrm{NS})$ or $>0(*)$ at $P \leq 0.05$

Table 2. Absolute and relative biomass of clonal Malus accessions grown $\approx 60 \mathrm{~d}$ in a composite field soil infested with apple replant pathogens (FS) or steam pasteurized (PS). Accessions are ranked by relative biomass indices (RBIs)

\begin{tabular}{|c|c|c|c|c|c|c|}
\hline \multirow[b]{2}{*}{ Clonal accessions } & \multirow{2}{*}{$\begin{array}{c}\text { Plants } \\
\text { (n) }\end{array}$} & \multicolumn{4}{|c|}{ Biomass (g/plant) } & \multirow[b]{2}{*}{$\mathrm{RBI}^{\mathrm{y}}$} \\
\hline & & $\mathrm{FS}$ & PS & Pooled SE & $\overline{P^{\mathrm{z}}}$ & \\
\hline$\overline{\mathrm{G} .5 \mathrm{~A}(\mathrm{G} 11 \text { rootstock })}$ & 15 & 0.96 & 4.08 & 0.17 & $*$ & $0.80^{*}$ \\
\hline CG.4013 (G13 rootstock) & 5 & 0.87 & 3.70 & 0.20 & $*$ & $0.77^{*}$ \\
\hline M. sieboldii-GMAL1881.f & 10 & 0.89 & 3.29 & 0.18 & $*$ & $0.74^{*}$ \\
\hline M. florentina-PI589317 & 15 & 1.36 & 4.67 & 0.16 & $*$ & $0.72^{*}$ \\
\hline M. hupensis-GMAL1878.i & 15 & 2.12 & 5.47 & 0.17 & $*$ & $0.67^{*}$ \\
\hline CG.7707 rootstock & 15 & 2.30 & 5.50 & 0.17 & $*$ & $0.65^{*}$ \\
\hline M.micromalus-GMAL1882.g & 5 & 0.24 & 0.63 & 0.20 & NS & $0.53^{*}$ \\
\hline M. orientalis-GMAL1461.h & 10 & 2.17 & 4.55 & 0.17 & $*$ & $0.52^{*}$ \\
\hline G.65 rootstock & 10 & 4.87 & 7.79 & 0.18 & $*$ & $0.32^{*}$ \\
\hline CG.8189 rootstock & 5 & 1.01 & 1.72 & 0.20 & NS & $0.32^{*}$ \\
\hline M. baccata-GMAL1883.h & 10 & 4.45 & 5.65 & 0.20 & NS & $0.19^{*}$ \\
\hline M. xanthocarpa-Xan & 10 & 3.17 & 3.84 & 0.18 & NS & $0.19^{*}$ \\
\hline M. spectabilis-PI589404 & 20 & 3.22 & 3.72 & 0.17 & NS & $0.12^{*}$ \\
\hline M. mandshurica-GMAL364.s & 30 & 3.15 & 3.58 & 0.16 & NS & $0.09^{*}$ \\
\hline G.30 rootstock & 10 & 2.91 & 3.19 & 0.17 & NS & $0.09^{\mathrm{Ns}}$ \\
\hline M. $\times$ domestica 'Bemali'-571 & 5 & 1.43 & 2.45 & 0.20 & NS & $-0.17^{\mathrm{Ns}}$ \\
\hline CG.6210 rootstock & 20 & 4.48 & 4.07 & 0.16 & NS & $-0.18^{\mathrm{Ns}}$ \\
\hline
\end{tabular}

${ }^{\text {zSignificant }(*)}$ or nonsignificant (NS) difference (Tukey-Kramer test, $P<0.05$ ) in dry weight of seedlings in FS and PS; pooled SE of mean difference in FS and PS

${ }^{y}$ Calculated as (PS - FS)/PS; RBIs $\leq 0(\mathrm{NS})$ or $>0(*)$ at $P \leq 0.05$ 
M. baccata-1883.h, M. xanthocarpa-Xan, CG.6210 rootstock (formerly known as CG.210), M. spectabilis-PI589404, $M$. mandshurica-364.s, and G.30 rootstock (Table 2).

Four of the seedling lots ( $M$. sieversiiPI600539, M. angustifolia-PI589773, M. coronaria Rehd.-PI600130, and M. ioensisPI600232), and three of the clones $(M$. $\times$ domestica 'Bemali'-571,CG.8189 rootstock (formerly CG.189), and M. micromalus Rehd.1882.g), grew relatively poorly in both FS and PS, suggesting that abiotic conditions in our test environment were unfavorable for these genotypes.

Relative biomass indices. The RBIs of seedling accessions ranged from 0.19 for $M$. sieversii-PI600539, to 0.87 for $M$. angustifolia-PI589773, demonstrating a broad range of relative growth in FS vs. PS (Table 1). The RBIs for most seedling accessions were substantially $>0$, because they were stunted in FS and vigorous in PS, indicating their susceptibility to ARD. The RBIs for two seedling lots (M. angustifolia-PI589727 and M. sieversiiPI600539) were statistically not $>0$, but we attributed this to extreme variation among seedlings of the former, and unfavorable abiotic conditions for the latter. For clonal accessions, the RBIs ranged from -0.18 for CG. 6210 rootstock, to 0.80 for G5.A rootstock, and for three clones the RBIs were statistically not $>0$ (Table 2). Two of the clonal rootstocks-G.30 and CG.6210-grew relatively well in both FS and PS, and may be tolerant of ARD. A third clone (M. domestica 'Bemali'-571) had an RBI significantly $<0$, but grew poorly in both FS and PS; this may be an intrinsically small clone with tolerance to ARD, or (more likely) its growth may have been curtailed by abiotic conditions in our test environment.

Parasitic nematodes in roots and soil. Rootlesion nematode (RLN) populations were quantified separately in bioassay roots and soil, because the relative proportions of RLN inside and outside of roots may be correlated with host-plant resistance or repellency to this pest (France and Brodie, 1995). The RLN counts in both seedling and clonal root systems were generally high, ranging from 90 to 796 , and from 58 to 454 per gram root fresh weight, respectively (Tables 3 and 4). The final RLN populations ranged from 0 to 117 , and from 16 to 252 , per $100 \mathrm{~cm}^{3}$ of rhizosphere soil for seedling and clonal accessions, respectively (Tables 3 and 4). Apparently none of the genotypes we tested were highly resistant or repellent to RLN, because its populations were much greater in roots than in soil for every accession.

The initial dagger nematode (DN) populations were substantial in our composite ARD soil; but unlike RLN, the DN failed to reproduce successfully on any accession tested, no stubby root symptoms of DN feeding were observed, and the minimal populations and negative RRIs observed for DN were not closely associated with accession biomass in FS (Tables 1 vs. 3, and 2 vs. 4). Others have reported that DN is vulnerable to physical disturbance and soil temperature or moisture
Table 3. Root-lesion (RLN) and dagger nematode (DN) population counts and relative population increase or decrease in roots and soil for seedling Malus accessions grown $\approx 60 \mathrm{~d}$ in a composite orchard soil infested with apple replant pathogens, ranked by relative reproduction indices (RRIs) for RLN.

\begin{tabular}{|c|c|c|c|c|c|}
\hline \multirow[b]{2}{*}{ Seedling accessions } & \multirow{2}{*}{$\begin{array}{c}\text { Plants } \\
\text { (n) }\end{array}$} & \multirow{2}{*}{$\begin{array}{l}\text { RLN count } \\
\text { (per g root) } \\
\quad \pm \text { SE }\end{array}$} & \multirow{2}{*}{$\begin{array}{l}\text { RLN count } \\
\text { (in } 100 \mathrm{~cm}^{3} \\
\text { soil) } \pm \text { SE }\end{array}$} & \multicolumn{2}{|c|}{ RRIs $^{\mathrm{z}}$} \\
\hline & & & & RLN & $\mathrm{DN}$ \\
\hline M. sieboldii-PI600029 & 6 & $796 \pm 267$ & $31 \pm 13$ & $12.8^{*}$ & $-1.0^{\mathrm{NS}}$ \\
\hline M. sieversii-PI600460 & 7 & $443 \pm 61$ & $43 \pm 10$ & $7.1^{*}$ & $-0.7^{*}$ \\
\hline M. fusca-PI600204 & 8 & $602 \pm 105$ & $48 \pm 23$ & $5.2^{*}$ & $-0.8^{*}$ \\
\hline M. ioensis-PI600275 & 10 & $325 \pm 32$ & $20 \pm 7$ & $4.8^{*}$ & $-0.8^{*}$ \\
\hline M. sieversii-PI600489 & 12 & $337 \pm 66$ & $50 \pm 11$ & $3.7^{*}$ & $-1.0^{\mathrm{NS}}$ \\
\hline M. sieversii-PI600559 & 10 & $327 \pm 81$ & $56 \pm 10$ & $3.3^{*}$ & $-1.0^{\mathrm{NS}}$ \\
\hline M. prunifolia-PI589816 & 15 & $342 \pm 62$ & $31 \pm 6$ & $3.2^{*}$ & $-1.0^{\mathrm{NS}}$ \\
\hline M. ioensis-PI590008 & 15 & $329 \pm 64$ & $17 \pm 5$ & $2.8^{*}$ & $-0.8^{*}$ \\
\hline M. angustifolia-PI589770 & 15 & $327 \pm 102$ & $15 \pm 3$ & $2.8^{*}$ & $-1.0^{\mathrm{Ns}}$ \\
\hline M. komarovi-PI600416 & 5 & $320 \pm 76$ & $19 \pm 10$ & $2.8^{*}$ & $-1.0^{\mathrm{NS}}$ \\
\hline M. sieversii-PI600563 & 14 & $290 \pm 59$ & $20 \pm 5$ & $2.7^{*}$ & $-1.0^{\mathrm{NS}}$ \\
\hline M. spectabilis-PI588893 & 15 & $282 \pm 78$ & $28 \pm 7$ & $2.4^{*}$ & $-1.0^{\mathrm{NS}}$ \\
\hline M. ioensis-PI589999 & 15 & $282 \pm 51$ & $26 \pm 9$ & $2.4^{*}$ & $-1.0^{\mathrm{NS}}$ \\
\hline M. baccata-PI589838 & 16 & $271 \pm 61$ & $28 \pm 6$ & $2.3^{*}$ & $-1.0^{\mathrm{NS}}$ \\
\hline M. prunifolia-PI594109 & 16 & $266 \pm 47$ & $33 \pm 6$ & $2.3^{*}$ & $-0.2^{\mathrm{NS}}$ \\
\hline M. orientalis-GMAL1461.k & 15 & $253 \pm 75$ & $33 \pm 6$ & $2.3^{*}$ & $-0.9^{*}$ \\
\hline M. sieversii-PI600539 & 8 & $238 \pm 73$ & $36 \pm 18$ & $2.0^{*}$ & $-1.0^{\mathrm{NS}}$ \\
\hline M. ioensis-PI590015 & 15 & $231 \pm 39$ & $31 \pm 8$ & $1.9^{*}$ & $-1.0^{\mathrm{NS}}$ \\
\hline M. sieversii-PI600496 & 12 & $240 \pm 64$ & $19 \pm 6$ & $1.9^{*}$ & $-0.8^{*}$ \\
\hline M. prunifolia-PI589930 & 17 & $223 \pm 27$ & $24 \pm 6$ & $1.8^{*}$ & $-0.8^{*}$ \\
\hline M. orientalis-GMAL1461.c & 15 & $206 \pm 43$ & $35 \pm 10$ & $1.7^{*}$ & $-0.8^{*}$ \\
\hline M. kirghisorum-PI600475 & 14 & $436 \pm 63$ & $63 \pm 11$ & $1.6^{\mathrm{NS}}$ & $-0.9^{*}$ \\
\hline M. angustifolia-PI589727 & 15 & $208 \pm 43$ & $20 \pm 6$ & $1.5^{*}$ & $-1.0^{\mathrm{NS}}$ \\
\hline M. kirghisorum-PI590043 & 15 & $195 \pm 35$ & $28 \pm 9$ & $1.5^{*}$ & $-0.9^{*}$ \\
\hline M. kirghisorum-PI600478 & 4 & $130 \pm 20$ & $19 \pm 3$ & $1.5^{*}$ & $-0.2^{\mathrm{Ns}}$ \\
\hline M. baccata-PI588870 & 15 & $205 \pm 44$ & $10 \pm 5$ & $1.4^{*}$ & $-1.0^{\mathrm{NS}}$ \\
\hline M. baccata-PI286599 & 15 & $192 \pm 22$ & $22 \pm 7$ & $1.4^{*}$ & $-0.8^{*}$ \\
\hline M. sieversii-PI600571 & 10 & $184 \pm 27$ & $25 \pm 7$ & $1.3^{*}$ & $-1.0^{\mathrm{NS}}$ \\
\hline M. baccata-PI437055 & 10 & $166 \pm 24$ & $31 \pm 9$ & $1.2^{*}$ & $-0.5^{\mathrm{ss}}$ \\
\hline M. sieversii-PI600427 & 8 & $262 \pm 52$ & $45 \pm 16$ & $1.0^{\mathrm{NS}}$ & $-0.8^{*}$ \\
\hline M. prunifolia-PI594102 & 15 & $151 \pm 29$ & $27 \pm 6$ & $1.0^{*}$ & $-0.1^{\mathrm{NS}}$ \\
\hline M. kirghisorum-PI589380 & 15 & $147 \pm 27$ & $24 \pm 4$ & $0.9^{\mathrm{Ns}}$ & $-0.8^{*}$ \\
\hline M. kirghisorum-PI600459 & 4 & $90 \pm 41$ & $24 \pm 10$ & $0.9^{\mathrm{Ns}}$ & $-0.6^{\mathrm{NS}}$ \\
\hline M. orientalis-PI600009 & 18 & $132 \pm 21$ & $14 \pm 4$ & $0.8^{\mathrm{Ns}}$ & $-0.8^{*}$ \\
\hline M. spectabilis-PI594100 & 20 & $124 \pm 27$ & $33 \pm 7$ & $0.7^{*}$ & $-1.0^{\mathrm{NS}}$ \\
\hline M. coronaria-PI600130 & 3 & $104 \pm 26$ & $0 \pm 0$ & $0.7^{\mathrm{Ns}}$ & $-1.0^{\mathrm{NS}}$ \\
\hline M. sieversii-PI600424 & 5 & $133 \pm 27$ & $15 \pm 4$ & $0.6^{\mathrm{NS}}$ & $-1.0^{\mathrm{NS}}$ \\
\hline M. angustifolia-PI600091 & 7 & $105 \pm 32$ & $31 \pm 8$ & $0.5^{\mathrm{Ns}}$ & $-1.0^{\mathrm{NS}}$ \\
\hline M. ioensis-PI600232 & 3 & $520 \pm 40$ & $117 \pm 16$ & $0.0^{\mathrm{Ns}}$ & $-0.9^{*}$ \\
\hline M. angustifolia-PI589773 & 5 & $474 \pm 271$ & $66 \pm 20$ & $-0.2^{\mathrm{Ns}}$ & $-0.7^{*}$ \\
\hline
\end{tabular}

${ }^{\mathrm{z}}$ Calculated as $(\mathrm{Pf}-\mathrm{Pi}) / \mathrm{Pi}$, where $\mathrm{Pf}=$ final nematode populations and $\mathrm{Pi}=$ initial populations per $\mathrm{g}$ of fresh root $+100 \mathrm{~cm}^{3}$ of bioassay soil; RRIs designated $\leq 0$ (NS) or $>0(*)$ at $P \leq 0.05$.

Table 4. Root-lesion (RLN) and dagger nematode (DN) population counts and relative reproduction increase or decrease in roots and soil, for clonal Malus accessions after $\approx 60 \mathrm{~d}$ growth in a composite orchard soil infested with various apple replant pathogens. Accessions are ranked by relative reproduction indices (RRI) for RLN.

\begin{tabular}{|c|c|c|c|c|c|}
\hline \multirow[b]{2}{*}{ Clonal accessions } & \multirow{2}{*}{$\begin{array}{c}\text { Plants } \\
\text { (n) }\end{array}$} & \multirow{2}{*}{$\begin{array}{c}\text { RLN count } \\
\text { (per g root) } \\
\pm \text { SE }\end{array}$} & \multirow{2}{*}{$\begin{array}{c}\text { RLN count } \\
\text { (per100 } \mathrm{cm}^{3} \\
\text { soil) } \pm \text { SE }\end{array}$} & \multicolumn{2}{|c|}{$\mathrm{RRI}^{\mathrm{z}}$} \\
\hline & & & & RLN & $\mathrm{DN}$ \\
\hline$\overline{\text { G.5A (G11 rootstock) }}$ & 15 & $355 \pm 63$ & $47 \pm 15$ & $5.7^{*}$ & $-0.2^{\mathrm{NS}}$ \\
\hline CG.4013 (G13 rootstock) & 5 & $391 \pm 82$ & $10 \pm 6$ & $5.7^{*}$ & $-0.7^{\mathrm{Ns}}$ \\
\hline M. micromalus-GMAL1882.g & 5 & $376 \pm 123$ & $14 \pm 7$ & $5.5^{\mathrm{Ns}}$ & $-1.0^{\mathrm{NS}}$ \\
\hline M. hupensis-GMAL1878.i & 15 & $341 \pm 34$ & $20 \pm 6$ & $5.0^{*}$ & $-0.8^{*}$ \\
\hline M. $\times$ domestica 'Bemali'-571 & 5 & $339 \pm 119$ & $15 \pm 7$ & $4.9^{\mathrm{Ns}}$ & $-0.7^{\mathrm{Ns}}$ \\
\hline CG.8189 rootstock & 5 & $251 \pm 26$ & $16 \pm 7$ & $3.4^{*}$ & $-1.0^{\mathrm{NS}}$ \\
\hline M. sieboldii-GMAL1881.f & 10 & $185 \pm 18$ & $29 \pm 10$ & $2.6^{*}$ & $-1.0^{\mathrm{NS}}$ \\
\hline CG.7707 rootstock & 15 & $156 \pm 34$ & $16 \pm 4$ & $1.9^{*}$ & $-0.8^{*}$ \\
\hline M. orientalis-GMAL1461.h & 10 & $139 \pm 47$ & $28 \pm 11$ & $1.8^{*}$ & $-0.5^{\mathrm{Ns}}$ \\
\hline M. florentina-PI589317 & 15 & $454 \pm 82$ & $58 \pm 13$ & $1.3^{*}$ & $-0.8^{*}$ \\
\hline M. xanthocarpa-Xan & 10 & $99 \pm 17$ & $26 \pm 8$ & $1.1^{*}$ & $-0.9^{*}$ \\
\hline G.65 rootstock & 10 & $58 \pm 8$ & $40 \pm 10$ & $0.6^{*}$ & $-0.8^{*}$ \\
\hline CG.6210 rootstock & 20 & $194 \pm 27$ & $20 \pm 5$ & $0.6^{\mathrm{Ns}}$ & $-0.9^{*}$ \\
\hline M. spectabilis-PI589404 & 20 & $436 \pm 51$ & $145 \pm 31$ & $0.4^{*}$ & $-0.5^{*}$ \\
\hline M. baccata-GMAL1883.h & 10 & $289 \pm 51$ & $262 \pm 25$ & $0.3^{*}$ & $0.4^{\mathrm{Ns}}$ \\
\hline M. mandshurica-GMAL364.s & 30 & $173 \pm 15$ & $20 \pm 4$ & $0.2^{\mathrm{Ns}}$ & $-0.7^{*}$ \\
\hline G.30 rootstock & 10 & $126 \pm 20$ & $36 \pm 110$ & $0.2^{\mathrm{Ns}}$ & $-0.5^{\mathrm{Ns}}$ \\
\hline
\end{tabular}

${ }^{\mathrm{z}}$ Relative reproduction index $(\mathrm{RRI})$ calculated as $(\mathrm{Pf}-\mathrm{Pi}) / \mathrm{Pi}$, where $\mathrm{Pf}=$ final nematode population and $\mathrm{Pi}$ $=$ initial population per $\mathrm{g}$ of fresh root $+100 \mathrm{~cm}^{3}$ of bioassay soil. The RRIs are designated $\leq 0$ (NS) or $>0(*)$ at $P \leq 0.05$. 
fluctuations, and we concluded that its failure to reproduce in our tests did not imply accession resistance to this pathogen (Sultan and Ferris, 1991).

Relative reproduction indices of $R L N$ in accessions grown on FS. We interpreted the observed RRIs for RLN in relation to plant growth of each accession, because host plants that are impaired by other biotic or abiotic factors would provide unfavorable conditions for reproduction of this migratory endoparasite. Combined root and soil populations at harvest were greater than the primary inoculum in FS for all but one severely stunted accession of M. angustifolia-PI589773 (Tables 1 and 3). There was a significant inverse correlation between relative reproduction indices of RLN and dry weights of clonal accessions in FS ( $r=0.78, \mathrm{n}=17, P=0.0002)$, indicating that RLN was an important factor limiting growth of apple in our soil.

Ten seedling accessions had relative reproduction indices (RRIs) for RLN that were statistically not $>0$ (Table 3 ), but most of these accessions grew so poorly in FS that their severely stunted and diseased root systems would have limited RLN reproduction during the final weeks of plant growth (Table 1). In contrast, three accessions of M. kirghisorum (PI600459, PI600475, and PI600478) grew adequately well in FS, with relatively low RLN populations and RRIs in their roots; further evaluation of $M$. kirghisorum for quantitative RLN resistance may be worthwhile. Two seedling accessions of $M$. sieversii (PI600427 and PI600563) grew adequately in FS, with relatively high RLN population densities and moderate or low RRIs (Tables 1 and $3)$; these accessions may have partial tolerance or resistance to RLN or ARD. The strong performance of $M$. sieversii in our tests was consistent with anecdotal reports from its provenance in Kazahkstan, where it is highly regarded as a rootstock for apple (J. Luby, personal communication).

Several clonal rootstocks (CG.6210, G.30, and G.65) and one clone of M. mandshurica364.s grew adequately well in FS, with relatively low nematode counts and RRIs (Tables 2 and 4). Three other clones (M. xanthocarpaXan, M. spectabilis-PI589404, and $M$. baccata-1883.h) grew equally well in FS and PS, with RRIs significantly $>0$ but low relative to RRIs of other accessions. $M$. xanthocarpa and G.65 rootstock suppressed RLN both in roots and surrounding soil. These seven clonal accessions may possess useful quantitative resistance to RLN, and tolerance of the disease complex in our test soil. The apparent tolerance of ARD in G.30 and CG.6210 rootstocks was especially interesting, because these clones have performed well in field tests on a variety of replant soils throughout North America (Robinson et al., 1996).

Many seedling and clonal accessions were stunted in both FS and PS, and had low RLN populations and reproduction indices (e.g., $M$. angustifolia-PI589773, M. ioensis-PI600232, and M. micromalus-1882.g). We designated the RLN and ARD responses of these accessions as indeterminate, which could be attrib-

Table 5. A matrix for classifying responses of Malus germplasm to apple replant disease involving rootlesion nematodes (RLN) and other pathogens in a pasteurized (PS) or nonpasteurized composite field soil (FS) mixture.

\begin{tabular}{lccc}
\hline \hline & \multicolumn{3}{c}{ Evaluation criteria } \\
\cline { 2 - 4 } $\begin{array}{l}\text { Host-plant ARD } \\
\text { response category }\end{array}$ & $\begin{array}{c}\text { Relative biomass index: } \\
(\mathrm{PS}-\mathrm{FS}) / \mathrm{PS}\end{array}$ & $\begin{array}{c}\text { Relative } \mathrm{RLN} \text { increase in } \\
\text { FS: }(\mathrm{Pf}-\mathrm{Pi}) / \mathrm{Pi}\end{array}$ & $\begin{array}{r}\text { Plant growth response after } \\
\approx 60 \mathrm{~d} \text { in FS and PS }\end{array}$ \\
\hline Susceptible & 0.5 to 1.0 & High, $\geq 0$ & Poor in FS, good in PS \\
Tolerant & 0.01 to 0.49 & High, $\geq 0$ & Good in both FS and PS \\
Resistant & $\leq 0$ & Low, $\leq 0$ & Good in both FS and PS \\
Immune & $\leq 0$ & $<0$, or -1 & Good in both FS and PS \\
Indeterminate & Variable & Variable & Poor in both PS and FS
\end{tabular}

uted to either biotic or abiotic limitations. Other researchers have classified such responses as intolerance, because both the host plant and pathogen are suppressed (Barker and Olthof, 1976). Another group of seedling and clonal accessions grew strongly in PS but were severely stunted in FS and supported high RLN population densities and RRIs (e.g., $M$. sieboldii Rehd.-PI600029, CG.4013 rootstock, and G.5A rootstock). We categorized their response as susceptibility to RLN or other pathogens in our test soil.

The classification and ranking of hostplant responses to ARD are problematic because of its variable and complex etiology. The relative roles of different root pathogens are controversial, and there are no commonly accepted guidelines to categorize ARD severity or host-plant resistance. In this context, we developed a matrix for classifying the relative responses of diverse apple genotypes to ARD in soils where RLN is a probable root pathogen (Table 5). With modifications reflecting the populations and virulence of other ARD pathogens at particular sites, such a matrix may be useful to researchers evaluating replant disease severity or host-plant resistance to ARD.

We observed substantial variation in apple genotype responses to biotic and abiotic factors that were associated with poor growth in a mixture of ARD soils in pots under greenhouse conditions. At least five fungal and one nematode genera including pathogenic species were isolated from diseased apple roots grown in an ARD soils mixture, and RLN susceptibility was an important factor limiting plant growth. Resistance or tolerance to the ARD complex was evident in some clonal rootstocks and accession seedling lots available from the Geneva ARS-PGRU, representing several apple species and interspecific hybrids. Further evaluations of these and other Malus germplasm resources for use in rootstock breeding programs could provide new management options for an important disease problem.

\section{Literature Cited}

Allen, W.R. and C. Marks. 1977. Chemical control and population studies of Pratylenchus penetrans on fruit tree understocks. Plant Dis. 61:84-87.

Barker, K.R. and T.H.A. Olthof. 1976. Relationships between nematode populations and crop responses. Annu. Rev. Phytopathol. 14:327353.

Benson, N.R., R.P. Covey, Jr., and W. Haglund. 1978. The apple replant problem in Washington State. J. Amer. Soc. Hort. Sci. 103:156-158.
Bolar, J.P., H.S. Aldwinckle, G.E. Harman, J.L. Norelli, and S.K. Brown. 1997. Endochitinasetransgenic McIntosh apple lines have increased resistance to scab. Phytopathology 87:S10.

Booth, C. 1966. The genus Cylindrocarpon. Mycol. Papers 104(14):1-56.

Braun, P.G. 1995. Effects of Cylindrocarpon and Pythium species on apple seedlings and potential role in apple replant disease. Can. J. Plant Pathol. 17:336-341.

Byrd, D., Jr., T. Kirkpatrick, and K. Barker. 1983. An improved technique for clearing and staining plant tissue for detection of nematodes. J. Nematol. 15:142-143.

Costante, J.F., W.F. Mai, J. Aleong, and R.M. Klein. 1987. Effects of apple rootstocks and nematicides on Pratylenchuspenetrans populations and apple tree growth. J. Amer. Soc. Hort. Sci. 112:441-444.

Culver, D.J., D.W. Ramming, and M.V. McKenry. 1989. Procedures for field and greenhouse screening of Prunus genotypes for resistance and tolerance to root-lesion nematode. J. Amer. Soc. Hort. Sci. 114:30-35.

Cummins, J.N. and H.S. Aldwinckle. 1983. Breeding apple rootstocks. Plant Breeding Rev. 1:294394.

Fernandez, C., J. Pinochet, D. Esmenjaud, M.J. Gravato-Nobre, and A. Felipe. 1995. Age of plant material influences resistance of some Prunus rootstocks to Meloidogyne incognita. HortScience 30:582-585.

France, R.A. and B.B. Brodie. 1995. Differentiation of two New York isolates of Pratylenchus penetrans based on their reaction on potato. J. Nematol. 27:339-345.

Forsline, P.L. 1988. Progress in developing a national program for Malus and Vitis germplasm maintenance and evaluation in the USA. Acta Hort. 224:33-38.

Hoestra, H. and M. Oostenbrink. 1962. Nematodes in relation to plant growth. IV. Pratylenchus penetrans (Cobb) on orchard trees Neth. J. Agr. Sci. 10:286-296.

Isutsa, D.K. 1998. Evaluating Malus germplasm for resistance or tolerance to apple replant problems. PhD Diss., Dept. Fruit and Veg. Sci., Cornell Univ., Ithaca, N.Y.

Isutsa, D.K., M.P. Pritts, and K.W. Mudge. 1998. A protocol for rooting and growing apple rootstock microshoots. Fruit Var. J. 52:107-116.

Jaffee, B.A., G.S. Abawi and W.F. Mai. 1982. Role of soil microflora and $P$. penetrans in an apple replant disease. Phytopathology 72:247-251.

Jaffee, B.A. and W. Mai. 1978. Growth reduction of apple seedlings by Pratylenchus penetrans as influenced by seedling age at inoculation. J. Nematol. 11:161-165.

Mai, W.F. and G.S. Abawi. 1981. Controlling replant diseases of pome and stone fruits in northeastern United States by preplant fumigation. Plant Dis. 65:859-864.

Mai, W.F. and P.G. Mullin. 1996. Plant-parasitic nematodes: A pictorial key to genera. 5th ed. Cornell Univ. Press, Ithaca, N.Y. 
Mai, W.F., I.A. Merwin, and G.S. Abawi. 1994. Diagnosis, etiology, and management of replant problems in New York cherry and apple orchard. Acta Hort. 363:33-41.

Mazzola, M. 1998. Elucidation of the microbial complex having a causal role in the development of apple replant disease in Washington. Phytopathol. 88:930-938.

McKenry, M., T. Buzo, J. Kretsch, S. Kaku, E. Otomo, R. Ashcroft, A. Lange, and K. Kelly. 1994. Soil fumigants provide multiple benefits; alternatives give mixed results. Cal. Agr. 48(3):22-28.

McSorley, R. 1998. Population dynamics, p. 109134. In: K.R. Barker, G.A. Pederson, and G.L. Windham (eds.). Plant nematode interactions. Agronomy (36). ASA, Madison, Wis.

Melakeberhan, H., A.L. Jones, P. Sobiczewski, and G.W. Bird. 1993. Factors associeated with the decline of sweet cherry trees in Michigan: Nematodes, bacterial canker, nutrition, soil $\mathrm{pH}$, and winter injury. Plant Dis. 77(4):266-271.

Merwin, I.A. 1995. Managing orchard replant disease without toxic soil fumigants. N.Y. State Fruit Quarterly 3(2):6-9.

Merwin, I.A., P.T. Pruyne, J.G. Ebel, K.L. Manzell, and D.J. Lisk. 1994. Persistence, phytotoxicity, and management of arsenic, lead and mercury residues in old orchard soils of New York State. Chemosphere 29(6):1361-1367.

Merwin, I.A. and W.C. Stiles. 1989. Root-lesion nematodes, potassium deficiency, and prior cover crops as factors in apple replant disease. J. Amer. Soc. Hort. Sci. 114:724-728.

Nelson, P.E., T.A. Tousson, and W.F.O. Marasas. 1983. Fusarium species: an illustrated manual for identification. Pennsylvania State Univ. Press, University Park.

Otto, G., H. Winkler, and K. Szabo. 1993. Investigations about the course of infestation of rootlets of apple seedlings by root pathogenic actinomycetes in soils with specific apple replant disease. Zentralblatt fuer Mikrobiologie 148:467-476.

Pruyne, P.T., I.A. Merwin, P.G. Mullin, and D.M. Gibson. 1994. Diagnosis of apple replant problems in New York orchard soils and evaluation of nematode-suppressive cover crops. Acta Hort. 363:211-228.

Robinson, T.L., J.N. Cummins, S.A. Hoying, and W.H. Smith. 1996. Use of dwarf apple rootstocks in high density apple planting systems. N.Y. Fruit Quarterly 2(2):9-12.

Sadowski, A., K. Scibisz, K. Tomala, T. Kozanecka, and M. Kepka. 1988. Negative effects of excessive nitrogen and potassium fertilization in a replanted apple orchard. Acta Hort. 233:85-94.

Samuels, G.J. and D. Bradyford. 1990. Variation in Nectria radicicola and its anamorph, Cylindrocarpon destructans. Mycol. Res. 94:433-432.

Sewell, G. 1981. Effects of Pythium species on the growth of apple and their possible causal role in apple replant disease. Ann. Appl. Biol.97:31-41.
Sewell, G.W.F, A.L. Roberts, and R.F. Elsey. 1992. Apple replant disease: The assessment and results of seedling bio-assays of growth responses to soil fumigation with chloropicrin. Ann. Applied Biol. 121:199-209.

Stiles, W.C. and W.S. Reid. 1991. Orchard nutrition management. Cornell Univ. Coop. Ext. Bull. 219.

Sultan, S.A and H. Ferris. 1991. The effect of soil moisture and soil particle size on the survival and population increase of Xiphinema index. Revue Nematol. 14:345-351.

Traquair, J.A. 1984. Etiology and control of orchard replant problems: A review. Can. J. Plant Pathol. 6:54-62.

Utkhede, R.S., T.C. Vrain and J.M. Yorston. 1992. Effects of nematodes, fungi and bacteria on the growth of young apple trees grown in apple replant disease soil. Plant Soil 139:1-6.

Vrain, T. and H. Daubney. 1986. Relative resistance of red raspberry and related genotypes to the root-lesion nematode. HortScience 21:14351437.

Wilcox, W. 1989. Identity, virulence, and isolation frequency of seven Phytophthora spp. causing root rot of raspberry in New York. Phytopathol. 79:93-101.

Young, L.D. 1998. Breeding for nematode resistance and tolerance, p. 187-208. In: K.R. Barker, G.A. Pederson, and G.L. Windham (eds.). Plant nematode interactions. Agronomy (36). ASA, Madison, Wis. 